\title{
RE-EXAMINING ANALYST SUPERIORITY IN FORECASTING RESULTS OF PUBLICLY-TRADED BRAZILIAN COMPANIES
}

\author{
RAFAEL C. GATSIOS ${ }^{1}$ \\ (iD) https://orcid.org/0000-0003-4364-7157 \\ FABIANO G. LIMA ${ }^{1}$ \\ (iD) https://orcid.org/0000-0003-4776-3673 \\ LUIZ E. GAIO \\ (iD) https://orcid.org/0000-0003-3106-7649 \\ TABAJARA PIMENTA JUNIOR ${ }^{1}$ \\ (D) https://orcid.org/0000-0001-5438-7800
}

To cite this paper: Gatsios, R. C., Lima, F. G., Gaio, L. E., \& Pimenta, T., Junior (2021). Re-examining analyst superiority in forecasting results of publicly-traded Brazilian companies. Revista de Administração Mackenzie, 22(1), 1-31. doi:10.1590/1678-6971/eRAMF210164

Submission: Sept. 12, 2019. Acceptance: June 8, 2020.

\footnotetext{
1 University of São Paulo (USP), Ribeirão Preto, SP, Brazil.

2 State University of Campinas (Unicamp), Limeira, SP, Brazil.
}

\section{(cc) BY This is an open-access article distributed under the terms of the Creative Commons Attribution License.}

\footnotetext{
This paper may be copied, distributed, displayed, transmitted or adapted for any purpose, even commercially, if provided, in a clear and explicit way, the name of the journal, the edition, the year and the pages on which the paper was originally published, but not suggesting that RAM endorses paper reuse. This licensing term should be made explicit in cases of reuse or distribution to third parties.

Este artigo pode ser copiado, distribuído, exibido, transmitido ou adaptado para qualquer fim, mesmo que comercial, desde que citados, de forma clara e explícita, o nome da revista, a edição, o ano e as páginas nas quais o artigo foi publicado originalmente, mas sem sugerir que a RAM endosse a reutilização do artigo. Esse termo de licenciamento deve ser explicitado para os casos de reutilização ou distribuição para terceiros.
} 


\section{ABSTRACT}

Purpose: This research examines the superiority of analysts over random walk models in forecasting the results of publicly-traded Brazilian companies in the short and long term.

Originality/value: The literature indicates the uncontested superiority of market analysts because of their temporal and informational advantages. However, recent international studies call for a re-evaluation of this superiority, indicating that, for certain company characteristics, and primarily for long-term estimates, the superiority of analysts is not confirmed.

Design/methodology/approach: This work evaluates the profit forecasting of analysts and simple and growth random walk models over the short and long term over 2010-2015 for publicly traded Brazilian companies, using the information available for the period with annual intervals.

Findings: The results indicate: 1 . the greater forecasting accuracy of simple random walk models compared to the growth random walk models; and 2. the greater forecasting accuracy of random walk models overall, with analyst forecasts only being superior for cases with three months of lag. The evidence suggests the forecasting superiority of the random walk models when compared to the market analysts' forecasts. The results suggest low efficiency of the forecasts of market analysts for the forecast of future results of publicly traded Brazilian companies in the analyzed period.

\section{KEYWORDS}

Earnings per share. Superiority of analysts. Market analysts. Time-series models. Random walk. 


\section{INTRODUCTION}

Company earnings constitute important information for investment decision making. Ramnath, Rock, and Shane (2008) indicate that market analysts are important agents in the task of evaluating investments. However, various studies indicate that their estimates might not accurately represent the behavior of future earnings. As analysts are offered various incentives, they generally present estimates with a positive bias (Bradshaw, Drake, Myers, \& Myers, 2012; Dugar \& Nathan, 1995; Francis \& Philbrick, 1993; Gatsios, Lima, \& Assaf Neto, 2016; Gu \& Wu, 2003; Martinez, 2007; McNichols \& O'Brien, 1997). Another option for predicting company earnings is the use of time-series forecasting models (Goojier \& Hyndman, 2006). In this line of research, studies arguing for the superiority of market analysts over time-series models compare the accuracy of their earnings forecasts.

These studies appeared in the literature throughout the 1970s and 1980s. After this initial period, they began to evaluate the factors contributing to the superiority or inferiority of market analyst forecasts of company earnings, particularly the former (Brown, Hagerman, Griffin, \& Zmijewski, 1987; Brown, Richardson, \& Schwager, 1987; Fried \& Givoly, 1982; Hopwood \& McKeown, 1982; O’Brien, 1988). Brown, Hagerman et al. (1987), in a seminal study on this topic, stated that forecasts by market analysts are superior to those from time-series models, and they described the reasons behind this conclusion. This study was complemented by similar research indicating that market analysts have information and timing advantages over time-series models (Brown, Hagerman et al., 1987; Brown et al., 1987).

However, after a period of disinterest in this line of research, some studies began to re-evaluate the superiority of market analysts and discussed when and under what circumstances estimates by market analysts would outweigh the predictions of time-series models (Ball \& Ghysels, 2017; Bradshaw et al., 2012; Lacina, Lee, \& Xu, 2011; Lorek \& Pagach, 2014). These recent studies discuss the costs and benefits of analysts' estimates and demonstrate the limitations of previous studies on the topic. Considering the limitations, the conclusions regarding the superiority of analysts cannot be generalized (Ball \& Ghysels, 2017; Bradshaw et al., 2012; Lacina et al., 2011; Lorek \& Pagach, 2014).

In Brazil, this stream of research, largely dominated by market analyst forecasts of company earnings, discusses the factors that determine the 
accuracy, dispersion, and bias of the estimates and their impact on the value of companies and of the capital markets (Beiruth, 2012; Boff, Procianoy, \& Hoppen, 2006; Dalmácio, Lopes, \& Sarlo Neto, 2013; Eid \& Rochman, 2006; Esteter, Pedreira, \& Barros, 2011; Gatsios \& Lima, 2014; Gatsios et al., 2016; Lima \& Almeida, 2015; Martinez, 2004, 2007; Martinez \& Dumer, 2014; Paulo, Lima, \& Lima, 2006; Silva, 1998).

Accordingly, this study presents the following research problem, motivated by recent studies reassessing the market analyst superiority in order to find new evidence in a developing capital market:

- Are earning estimates from market analysts superior to those provided by random walk models in Brazil?

To answer this research problem, this study analyzed the market analyst and random walk model forecasts on publicly traded Brazilian companies for 2010, 2011, 2012, 2013, 2014, and 2015. The forecasts were evaluated in different samples for short and long terms, with and without growth, and for each annual earnings period.

The joint analysis shows that market analysts' forecasts of publiclytraded Brazilian companies' future earnings over the period were not superior. These research findings counter the uncontested arguments in the traditional literature regarding the superiority of market analysts in forecasting future company earnings relative to time-series models (Brown, Hagerman et al., 1987; Fried \& Givoly, 1982; Hopwood \& McKeown, 1982; O'Brien, 1988). The superiority of analysts verified in the case of Brazil was only verified for the estimates published in December with a threemonth lag period.

\section{LITERATURE REVIEW AND HYPOTHESIS}

Initial studies on analyst superiority only compared the predictions of market analysts and time-series models.

Brown and Rozeff (1978) evaluated the superiority of market analyst predictions for 50 American companies from 1972 to 1975, using quarterly data. The study used a forecast horizon of one to five quarters, and, through the mean difference test, it showed greater accuracy from market analysts. Fried and Givoly (1982), while trying to generalize the abovementioned studies, worked with a sample of 424 publicly traded American companies 
from 1969 to 1979. The study used annual data and an eight-month forecast before the end of the corporate fiscal year. The forecast errors of the analysts and the time-series model were $16.4 \%$ and $19.3 \%$, respectively.

After this initial period, in which the studies only evaluated the magnitude of analyst superiority, research began looking for the factors determining this superiority. With this objective in mind, Brown, Hagerman et al. (1987) evaluated the earnings of 233 American companies from 1975 to 1980 and, using quarterly data, forecasted the subsequent one to four quarters. They demonstrated an error rate of $28.7 \%$ for analysts and $33.0 \%$ for time-series models. Investigating the results, the authors argued that this superiority is negatively related to the forecast horizon, given that the closer the horizon of analysts' forecasts, the lower the error.

Brown et al. (1987) completed a similar study with quarterly and annual data from companies, evaluating the superiority of the analysts over random walk models. Their results also demonstrated the superiority of market analysts. The forecast was performed for one month before the disclosure of earnings up to 18 months earlier. The main result of this research indicated that the superiority is positively related to the size of the company.

Based on the results of these two studies on market analyst forecasts, the literature began attributing this superiority to two aspects: 1 . information advantage and 2. timing advantage. The information advantage arises from the fact that market analysts have more informational content to provide estimates than to do time-series models. This includes information about the company, industry, capital market, and economic information, which comprises a larger set of information available for forecasting. The second advantage of the analysts is related to information completion time. This means that analysts can make estimates after a company has released its earnings, while time-series models only use historical information. This timing advantage allows analysts to add more information as the earnings forecasting process progresses.

For the Brazilian case, Silva (1998) follows the international literature and presents evidence regarding the superiority of market analysts for publicly traded companies. The study evaluates publicly traded Brazilian companies from 1994 to 1996, using information from Gazeta Mercantil. The results follow the international literature and indicate that, in the case of Brazil, market analysts are more accurate than time-series models when in short and medium-term estimates, with no significant differences for longer predictions. Nonetheless, it is important to highlight the small sample used for this research (38 companies). 
After a period of disinterest and given the conclusions regarding the uncontested superiority of the analysts, some studies started to re-evaluate the superiority of market analysts from different aspects.

According to Bradshaw et al. (2012), the studies that established this consensus within the literature were carried out for short-term forecasts and, as such, cannot be extrapolated to long-term forecasting. According to the authors, these studies were conducted in developed markets, with small samples, short periods of forecasting and analysis, and using companies that have survived the market. In this sense, Brown, Hagerman et al.'s (1987) conclusion that market analysts are superior is only valid for this type of sample.

In line with Cheng, Fan, and So (2003), these long-term estimates from analysts present an optimistic bias and do not add information when compared to forecasts from time-series models. Other studies confirm an optimistic bias of forecasts from analysts (Chiang \& Chia, 2005; Dechow, Hutton, \& Sloan, 2000; Dechow \& Schrand, 2004; Gu \& Wu, 2003; Kothari, 2001; Lim, 2002; Schipper, 1991). As previously discussed, this bias can be associated with economic incentives for, or personal characteristics of, these agents at forecasting. This makes it necessary to separately evaluate these two possibilities of bias generation (Kothari, 2001).

Based on the points presented above, recent studies started debating the superiority of market analysts to time-series models. These works indicate that the superiority of market analysts is not uncontested and that forecasting the future earnings of companies using time-series models can be useful for investment decision making and research in other areas of knowledge (Bradshaw et al., 2012; Grigaliuniene, 2013; Lacina et al., 2011; Lorek \& Willinger, 2002). Accordingly, research demonstrates that the factors determining the superiority of market analysts - company size, analyst coverage, earnings volatility, company listing in portfolios, dispersion of forecasts from analysts, and forecast-horizon - may be responsible for altering the superiority of analyst forecasts for long-term estimates. In this sense, the relevance of this study is justified, given that it assesses the superiority of market analysts in a country with a developing capital market and very little research on this topic.

Based on recent studies that reassessed the superiority of analysts, we, therefore, propose the following hypothesis:

- Hypothesis 1: Market analysts are not superior to predicting the profits of public companies. 


\section{METHODOLOGY}

The data used for this work were obtained from the Thomson Reuters ${ }^{\circledR}$ platform, as well as from the $\mathrm{I} / \mathrm{B} / \mathrm{E} / \mathrm{S}{ }^{\circledR}$ and Thomson Financial ${ }^{\circledR}$ databases. The $\mathrm{I} / \mathrm{B} / \mathrm{E} / \mathrm{S} \otimes$ database is widely used in the literature regarding the forecasting of future earnings of companies and research on market analysts. This fact is relevant to avoid the possibility that the database presents incorrect information about the disclosed data.

In this research, the study evaluated the results regarding the superiority of market analyst predictions for 2010 to 2015 for publicly traded Brazilian companies, using the information available for the period, with annual intervals. Earnings forecasts of companies were evaluated in the short and long term for both market analysts and random walk models. The short term refers to forecasts up to one year before earnings are disclosed. Projections with lags of two to three years are considered long-term forecasts.

To evaluate the behavior of the estimates from analysts in periods closer to the results, the data were observed in March, June, September, and December of each year. Accordingly, forecasts with one, two and three-year lags are based on the valuations conducted in the highlighted months. Unlike forecasts from analysts, only results released by the company in the previous year were available for forecasts from random walk models.

The whole sample of this study is composed of 3,751 data observations from publicly traded Brazilian companies from 2010 to 2015. This set of observations consists of short and long-term forecasts for 227 companies. To prevent outliers from interfering in the analysis, this study applied a winsorizing technique, which is a statistical procedure in which values above or below critical percentiles are replaced with data from the upper or lower limit of these percentiles (95\%). This technique was applied according to methods described in studies by Brown et al. (1987), Fried and Givoly (1982), and Lacina et al. (2011).

The forecast comparison method is used in this study, following the literature that has suggested a need to re-evaluate the superiority of market analysts. According to the literature, this study applies univariate analysis to test the differences of means, in order to evaluate forecasts in the short and long terms, grouping them according to evidence from previous research (Ball \& Ghysels, 2017; Bradshaw et al., 2012; Lacina et al., 2011; Lorek \& Pagach, 2014). In addition, this method is supported by seminal studies in the same research area (e. g., Brown, Hagerman et al., 1987; Brown et al., 1987). 


\subsection{Variables}

The ANALYSTERROR variable evaluated the accuracy of the forecasts from market analysts. It was constructed in line with Cotter, Tarca, and Wee (2012) and is supported by the literature (Bradshaw et al., 2012; Lacina et al., 2011; Lang \& Lundholm, 1996; Hope, 2003; Martinez, 2004). This variable is presented by Equation 1:

$$
\text { ANALYSTERROR }=\left|\frac{F(j, r)-A_{j, r}}{A_{j, r}}\right|
$$

For short-term forecasting (up to one-year lag), ANALYSTERROR is defined as the absolute difference (module) between the median forecast from analysts $F(j, r)$ and the adjusted earnings per share (EPS) of company $j$ in the period of earnings disclosure $\left(A_{j, r}\right)$ divided by the adjusted annual EPS of company $j$ throughout earnings disclosure $\left(A_{j, r}\right)$.

For forecasts with more than a one-year lag (long-term), estimates of analysts are scarce in the Brazilian database, inhibiting the construction of analyst forecasts. This study used the methodology proposed by Lacina et al. (2011) and Bradshaw et al. (2012), which uses the long-term growth rate of median estimates from market analysts, LTG, available in the I/B/E/S ${ }^{\circledR}$ database, as presented in Equation 2.

$$
F_{j,(t+\tau)}=F_{j,(t)} \times\left(1+L T G_{(\tau)}\right)
$$

in which:

$F_{j,(t+\tau)}$ : the analyst forecast for company $j$ for future date $t+\tau$;

$F_{j,(t)}$ : the analyst forecast for company $j$ for date $t$, available in the database; LTG: the long-term growth rate of corporate earnings, the median of consensus of analysts;

Given: $\tau=1$ and 2 .

The accuracy of random walk models was evaluated using the difference between previous and current earnings disclosed by the company (Bradshaw et al., 2012; Lacina et al., 2011). The use of this methodology is justified by both the design of this research, which seeks to compare the estimates from market analysts with user-friendly and straightforward forecasting models, 
and its theoretical framework, which indicates the random walk behavior of the company profit series, as highlighted by Brown (1993).

Additionally, this study followed the methodology presented by Lacina et al. (2011) and Bradshaw et al. (2012) when using economic variables for the construction of a random walk model with growth. In this construction, the forecast is multiplied by the growth rate in question. This research uses Brazil's real Gross Domestic Product (GDP) growth rate for this period, discounting the Broad National Consumer Price Index (Índice Nacional de Preços ao Consumidor Amplo [IPCA]) for this period as a growth factor for the estimates. Given that the real GDP growth rates found for the analyzed period were negative, these values were replaced by a zero-growth rate.

Although the use of random walk is traditional and quite simplistic, it is still largely effective in predicting models of short time series. Due to their parsimonious characteristic, they tend to perform satisfactorily in univariate forecasts. The recent study by Baghestani and Toledo (2017) shows this. The random walk models do not require the use of more complex (multivariate) models in the daily routine of the financial market.

The simple random walk (RWFORE) and the random walk with growth (RWDFORE) variables, presented in equations 3 and 4, were constructed to build the forecast variable for random walk models with and without growth.

$$
R W F O R E_{j,(t)}=\operatorname{EPS}_{j(t-1)}
$$

in which EPS ${ }_{t-1}$ : the earnings per share of company $\mathrm{j}$ in the period before the forecast.

$$
R W D F O R E_{j,(t+\tau)}=E_{t-1} \times\left(1+g_{\tau}\right) \in \tau(1,2)
$$

in which:

$E P S_{t-1}$ : represents the earnings per share of company $j$ in the period before the forecast;

$\mathrm{g}$ : is the real GDP growth rate of Brazil for this period (ex-post rate).

After setting the forecast calculations for RWFORE and RWFORE with and without growth, this study presents the RWERROR and RWDERROR variables, representing the forecast error of the random walk models with and without growth, in equations 5 and 6 : 


$$
\begin{gathered}
\operatorname{RWERROR}_{j, t}=\left|\frac{\operatorname{RWFORE}_{j, t}-A_{j, r}}{A_{j, r}}\right| \\
\operatorname{RWDERRO}_{j, t}=\left|\frac{R W D F O R E_{j, t}-A_{j, r}}{A_{j, r}}\right|
\end{gathered}
$$

in which the forecast error is defined by the absolute difference between the estimates from random walk models without growth $\left(R W F O R E_{j, t}\right)$ and with growth $\left(R W D F O R E_{j, t}\right)$ for company $j$ in period $t-1$ or the annual EPS of company $j$ in reporting period $A_{j, r}$ divided by the annual EPS of company $j$ in the reporting period $A_{j, r}$.

To evaluate the superiority of market analysts, the variable SRW was calculated. This superiority was compared with the forecasts from simple random walk models; in other words, the difference between the ANALYSTERROR and RWERROR variables was analyzed. Likewise, the SRWD variable, which measures the superiority of analysts over estimates from random walk models with growth, was calculated. Random walk models with growth measure the difference between the ANALYSTERROR and RWDERROR variables, as shown in equations 7 and 8 .

$$
\begin{gathered}
S R W_{j, t}=A^{A N A L Y S T E R R O R ~} \\
j, t
\end{gathered}
$$

As displayed in the literature review, recent evidence indicates that superiority of analysts is related to the following aspects: 1 . forecast horizon; 2. company age; 3 . number of analysts who cover the company; 4. company size; 5 . earnings volatility; 6 . forecast dispersion; 7. participation in market indexes; and 8. disclosure of negative corporate earnings (Ball \& Ghysels, 2017; Bradshaw et al., 2012; Lacina et al., 2011; Lorek \& Pagach, 2014). The evidence is summarized in Figure 3.1.1. 


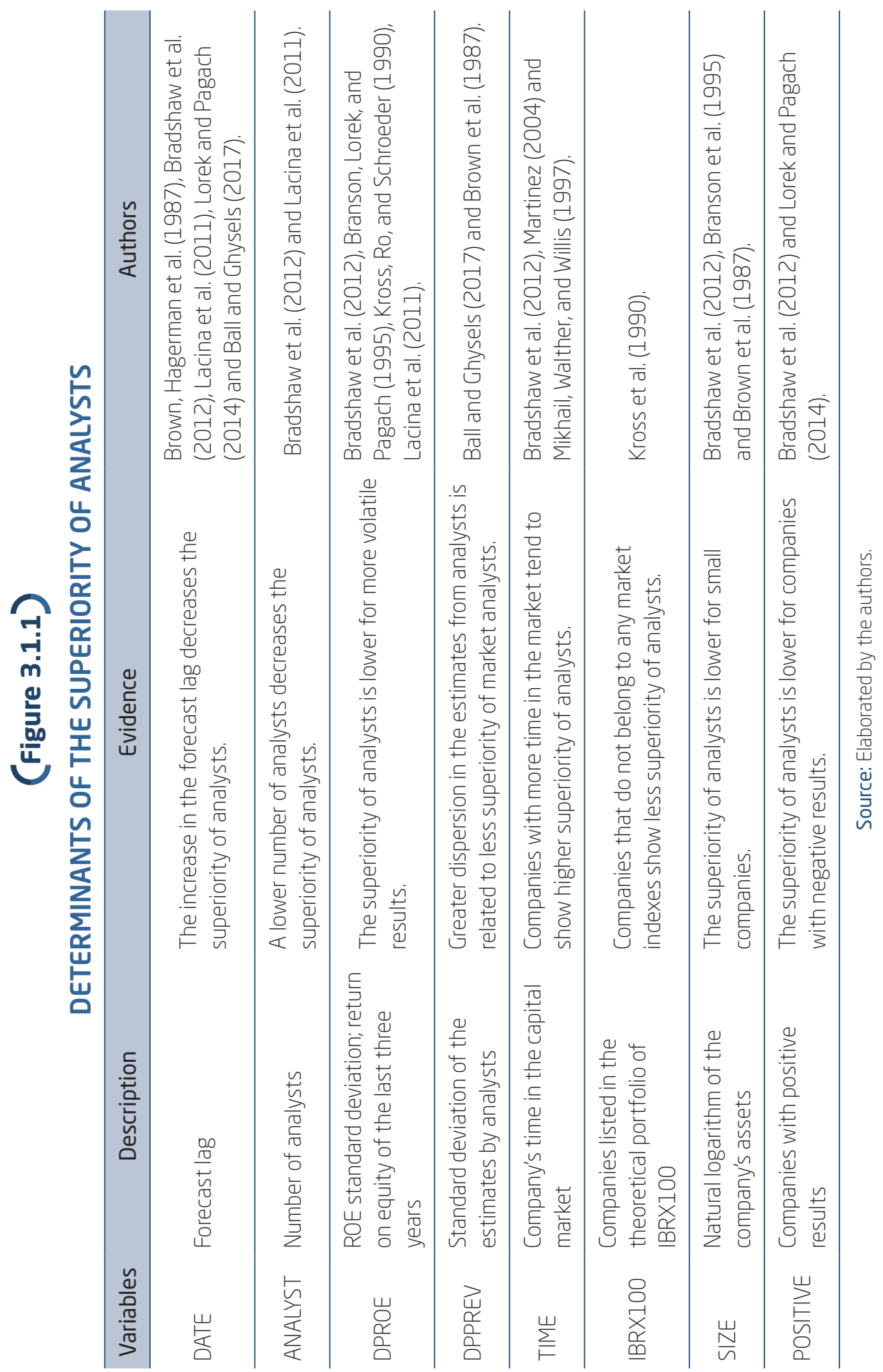




\section{RESULTS}

\subsection{Analysis of forecast errors}

The initial analysis examines the forecast error of analysts and time-series models using different lags (years and months). Figure 4.1.1 presents a mean difference test between the forecast error of analysts (ANALYSTERROR), the forecast error of simple random walk models (RWERROR), and the forecast error of random walk models with growth (RWDERROR). The results from the analysis of the whole sample and the separated lags per year reinforce the initial analysis presented in the descriptive statistics. For the whole sample, the mean for the forecast error of market analysts (ANALYSTERROR) variable, 0.8413 , is higher than the mean for the forecast error of simple random walk models (RWERROR) variable, 0.7591. This difference is statistically significant at the $1 \%$ level. In other words, the forecasts from analysts are less accurate than those from simple random walk models. The difference between the means of the forecast error of analysts (ANALYSTERROR) and the forecast error of random walk models with growth (RWDERROR) variables was not statistically significant at a level of $10 \%$. That is, there is no difference between the forecasts from analysts and random walk models with growth. Accordingly, the accuracy of the estimates from these models is inferior to those obtained from simple random walk models.

(Figure 4.1.1)

MEAN DIFFERENCE TEST - FORECAST ERROR OF MARKET ANALYSTS AND RANDOM WALK MODELS

\begin{tabular}{lll}
\hline \multicolumn{1}{c}{ Variable } & Mean & T-test \\
\hline ANALYSTERROR & 0.8413 & \\
\hline RWERROR & 0.7591 & $0.0004^{\star \star *}$ \\
\hline RWDERROR & 0.8499 & 0.6268 \\
\hline
\end{tabular}

Significance levels: * $10 \%$; $*$ $5 \%$; ${ }^{\star \star \star} 1 \%$.

Source: Elaborated by the authors. 
In Figure 4.1.2, the analysis (performed over two years) confirms the results of previous analyses. For forecasts with up to a one-year lag, the mean of the forecast error of analysts (ANALYSTERROR) variable is lower than the mean of the period (0.7974), and it increases for forecasts with up to two and three-year lags (0.8609 and 0.9440, respectively). This result, which is expected by the literature, indicates that the lag is important for the quality of forecasts from analysts.

In the same fashion, the forecast error of the simple random walk models (RWERROR) variable increases with the lag for the simple random walk model as well. A lag of up to one year leads to an error of 0.7458 . The error increases to 0.7679 for forecasts with a two-year lag and to 0.7857 for a lag of three years. Nevertheless, this increase is lower than that for market analysts.

The difference between the forecast error of analysts (ANALYSTERROR) and the forecast error of the simple random walk models (RWERROR) variables is statistically significant for all the sample years. This means that the random walk model forecasts are more accurate than the analyst forecasts for both the whole sample and the individual years. However, the results of the random walk model with growth, which are like the previous evaluations, are less accurate than the forecasts from the simple random walk model.

Figure 4.1.2 shows the results segregated by month. Only for December is the short-term forecast error of market analysts smaller, statistically and significantly, than simple random walk models, confirming the finding from the descriptive statistics. The forecast errors for September are not significantly different. By contrast, the simple random walk model forecasts for June and March are more accurate. For none of the periods, however, is the long-term forecast error lower for market analysts.

These results indicate, in line with the literature, that the more lagged the forecasts, the less superior are the analysts (Bradshaw et al., 2012; Brown, Hagerman et al., 1987; Hopwood \& McKeown, 1982; Kross et al., 1990; Lacina et al., 2011; O’Brien, 1988). The mean difference tests confirm the ratios in the correlation matrix, which are similar, in general, to those presented in studies on analyst superiority (Bradshaw et al., 2012; Brown, Hagerman et al., 1987; Hopwood \& McKeown, 1982; Kross et al., 1990; Lacina et al., 2011; O’Brien, 1988).

The mean difference tests demonstrate that random walk model forecasts are more accurate than market analysts' estimates for Brazil. This finding is in line with re-evaluation studies on market analyst superiority for longterm estimates (Bradshaw et al., 2012; Lacina et al., 2011). 


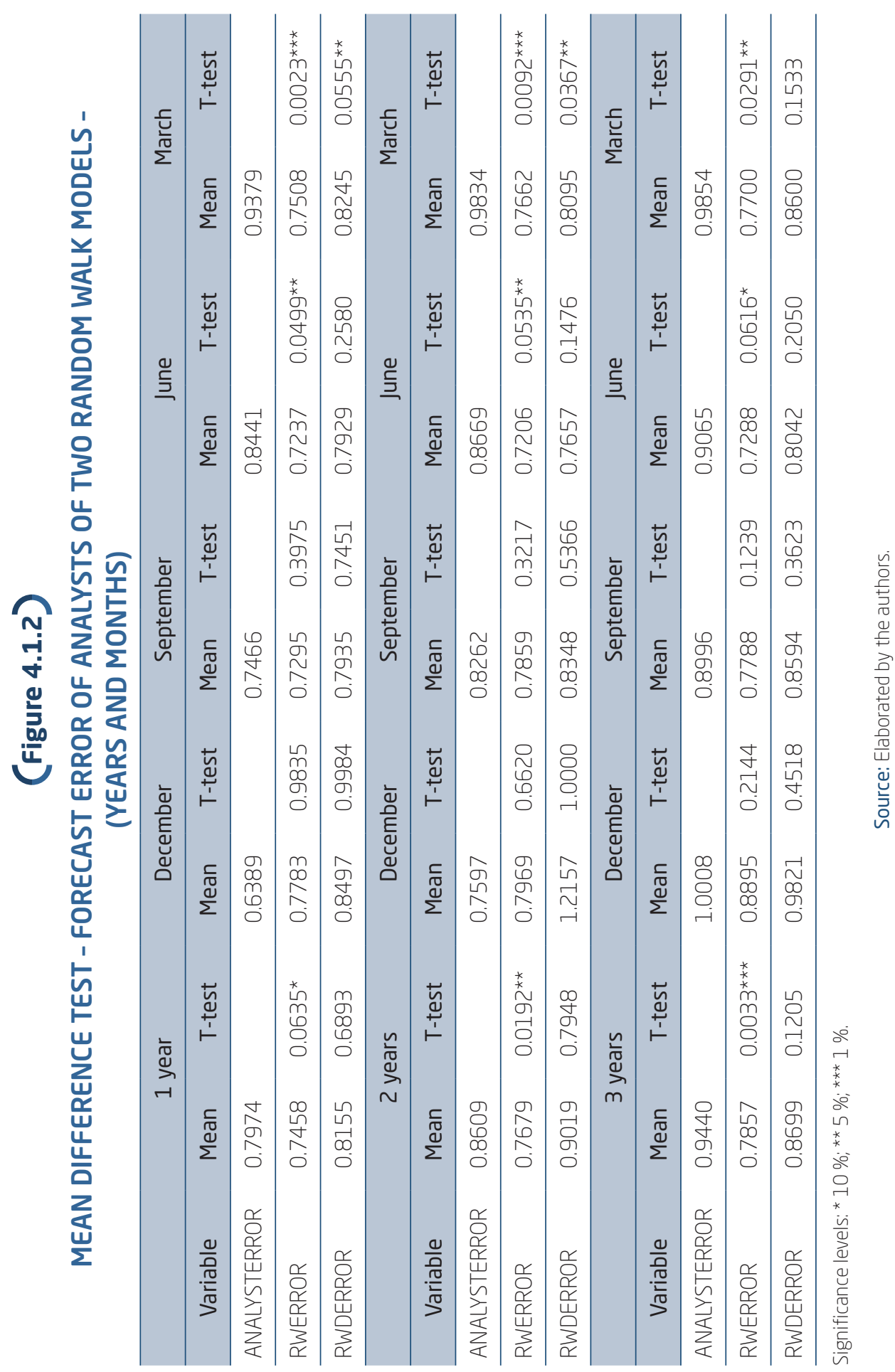


The joint analysis of these observations revealed that forecasts from market analysts are less accurate than random walk model estimates for short and long terms in the case of Brazil. This result conforms with the findings of Ball and Ghysels (2017), although they use a more complex time-series methodology to predict the future earnings of companies. Their objective was to evaluate short- and long-term forecasts and how the factors mentioned in the literature impact the superiority of market analysts in the case of Brazil. Their study evaluated the superiority of market analysts for March, June, September, and December of the sample years.

\subsection{Superiority of analysts}

To develop further analysis and evaluate the superiority of analysts in different samples, the study compares the results of analyst superiority and random walk models. Figure 4.2.1 presents the results of the variables of the superiority of market analysts over the simple random walk models (SRW), and the superiority of analysts overestimates from random walk models with growth (SRWD) by year.

Forecasts with one-year lag: 480 in December, 502 in September, 464 in June, and 569 in March. This behavior is similar for other lag periods, with the only difference being the total data available. This fact is justified by the absence of data for analysts to make their forecasts with lags of more than one year, and using the long-term growth rate (LTG) for the completion of these forecasts.

The one-year lagged sample displays a positive mean of 0.0061 for the superiority of market analysts over the single random walk models (SRW) variable. This means that the forecasts from simple random walk models are superior to those from analysts. Evaluating the results by month in the first year yields a December estimate of -0.1513 . This result indicates that analyst errors are smaller than forecast errors of simple random walk models.

However, this result loses significance as the lag increases, and for forecasts made in September, the value is still negative (-0.0273), although much lower than the December estimate. According to this analysis, the longer forecasts of June and March have positive estimates, with values of 0.0539 and 0.1272 , respectively. In other words, the estimates from simple random walk models for this period are superior to those from market analysts. 


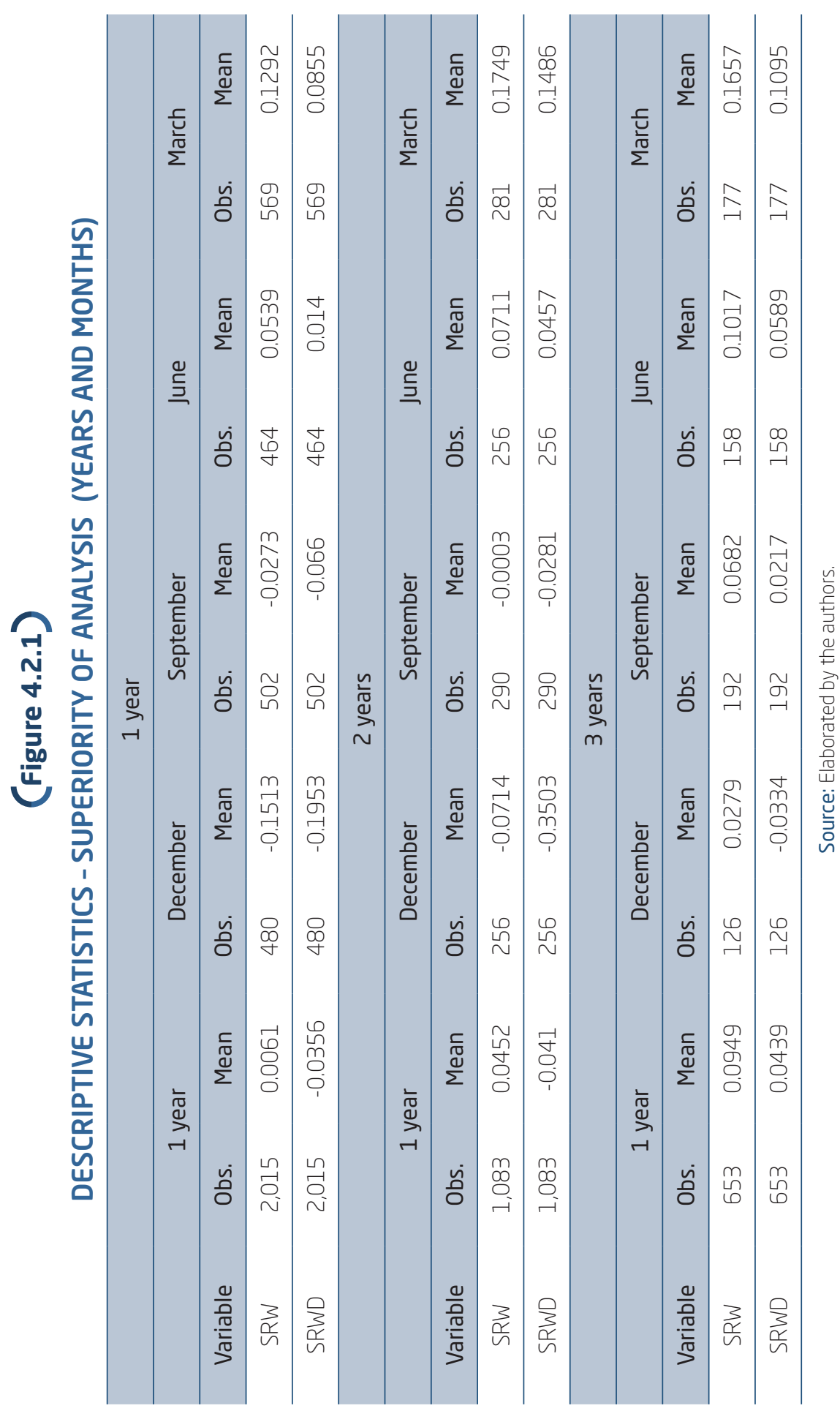


The superiority of market analysts over the simple random walk models (SRW) variable displays a similar behavior for forecasts with both one- and two-year lags across March, June, September, and December, but the magnitudes differ in all cases. In other words, forecast error is higher for analysts than simple random walk models for the entire period of two years, with a value of 0.0452 for the one-year lag and a higher value, but the same sign for the two-year-lagged random walk model. This result indicates that analysts are less accurate at forecasting earnings than random walk models and that the difference is greater for forecasts with two years of lag compared to short-term lags.

In all cases, forecast errors are greater for analysts than with the simple random walk model (SRW) for the three-year lag period. The greater the lag, the greater the difference between the errors, which explains the smaller difference for the December estimate (0.0279). The long-term forecast results, which confirm the conclusions of the short-term analysis, suggest that the use of September and December estimates, in addition to the longterm growth rate (LTG), provides greater accuracy for the two-year lag. Nevertheless, the superiority of random walk models was confirmed for forecasts with a three-year lag in all periods.

A comparison of analyst forecasts and the estimates of random walk models with growth (SRWD) shows that the models behave just as in the previous analysis, although their accuracy is lower than that of simple random walk forecasts. These results reinforce this work's research questions and suggest that information users consider only forecasts made close to the disclosure of earnings.

It is important to highlight that short-term forecasts plus the long-term growth rate (LTG) were used for long-term forecasting. This makes these forecasts, on occasion, more accurate than those made with a one-year lag in March. This result confirms the low predictive capacity of Brazilian analysts since forecasts for previous periods plus the long-term growth rate (LTG) were higher than the forecasts performed in March of the current year.

As shown by the previously discussed studies assessing the superiority of analysts, the superiority of analysts is evaluated according to several factors: whether companies report positive or negative results; whether they are listed in the IBRX1000 index; whether they have a large number of analysts covering them; whether they are large or small; whether they have high or low variability in results; whether they have high or low variability in the dispersion of estimates from analysts; and whether they have been present for a long or short time in the capital market. 
These factors, presented in the literature as determinants of the superiority of analysts, are analyzed in figures 4.2.2 and 4.2.3 through mean difference tests applied to forecasts from simple random walk models and random walk models with growth, the superiority of market analysts over the simple random walk models (SRW) and the superiority of analysts over estimates from random walk models with growth (SRWD), respectively.

In figures 4.2.2 and 4.2.3, two analysis groups were formed for each variable: 0 and 1. group 1 was composed of companies listed in IBRX100 with positive results that had multiple analysts, size, forecast dispersion, and time in the market higher than the mean of the study sample variables; and group 0 refers to the other observations for each of the variables.

The joint analysis of the data in the short-term sample, except for the variable forecast dispersion (DPPREV), confirms greater accuracy for analysts of group 1 companies and the models of Group 0 companies. In other words, this result confirms the proposed relationships between the determinant factors and the superiority of analysts, indicating that they are crucial for defining the actual superiority of analysts in predicting future results of companies, except for the variables earnings volatility (DPROE) and forecast dispersion (DPPREV), for which analysts are expected to be superior for Group 0 companies.

However, the superiority of long-term analysis was confirmed only for the variables size of the company (SIZE) (two and three years) and company age (TIME) (two years) in group 1. In other words, even for the groups in which analysts have a greater advantage, they are not able to provide more accurate forecasts than the random walk models.

These results are important, given that they differentiate the research findings concerning the international studies re-evaluating the superiority of analysts; in the short term, complete superiority of analysts was expected, while in the long term, they were expected to be more accurate for the group of companies where they have a greater forecasting advantage (group 1), except for the variables forecast dispersion (DPPREV) and earnings volatility (DPROE).

However, the average difference tests indicate greater forecasting accuracy for the random walk models compared with market analysts in the Brazilian case. Only for forecasts with a lag of three months was analyst superiority confirmed. 


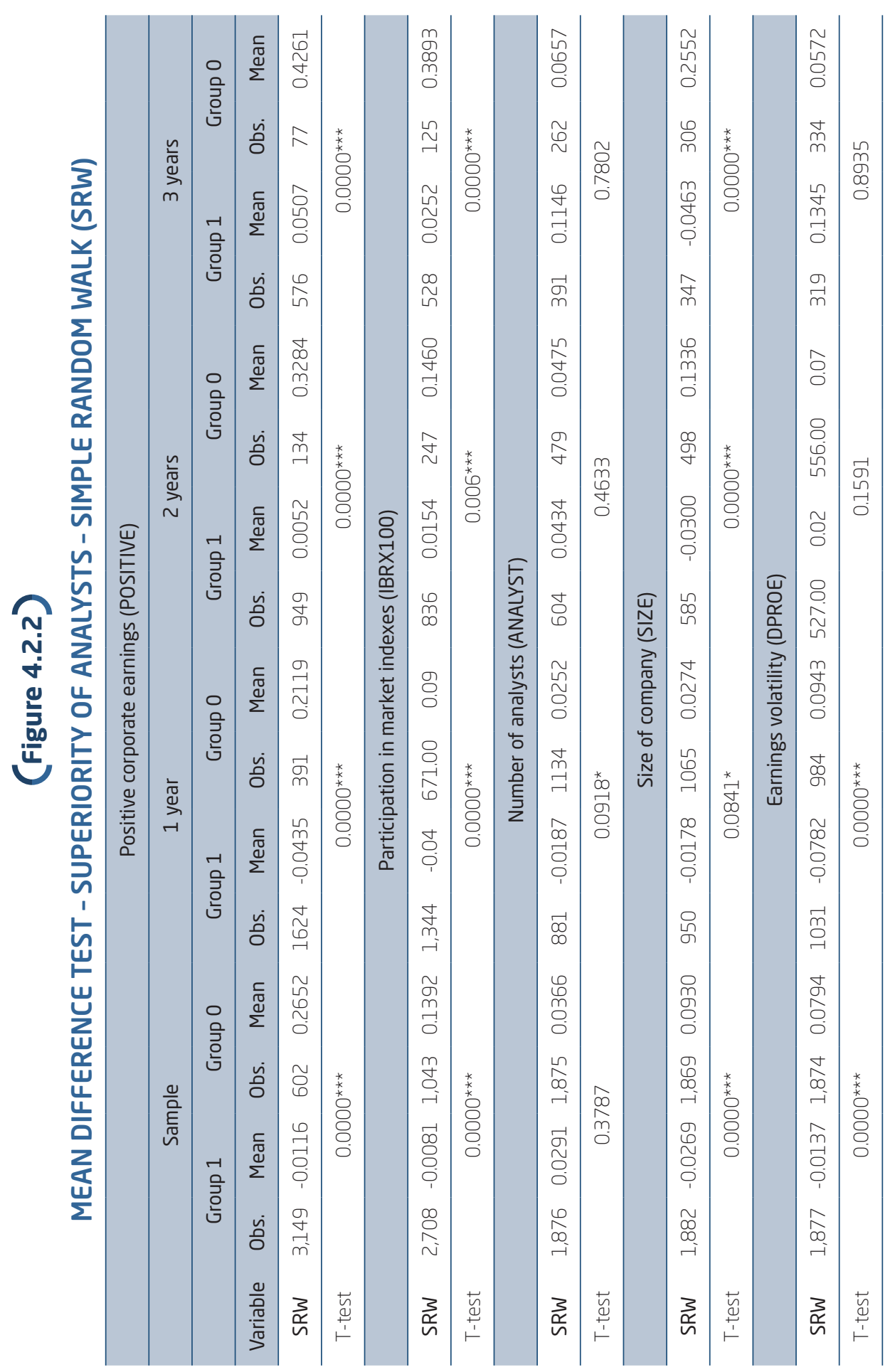




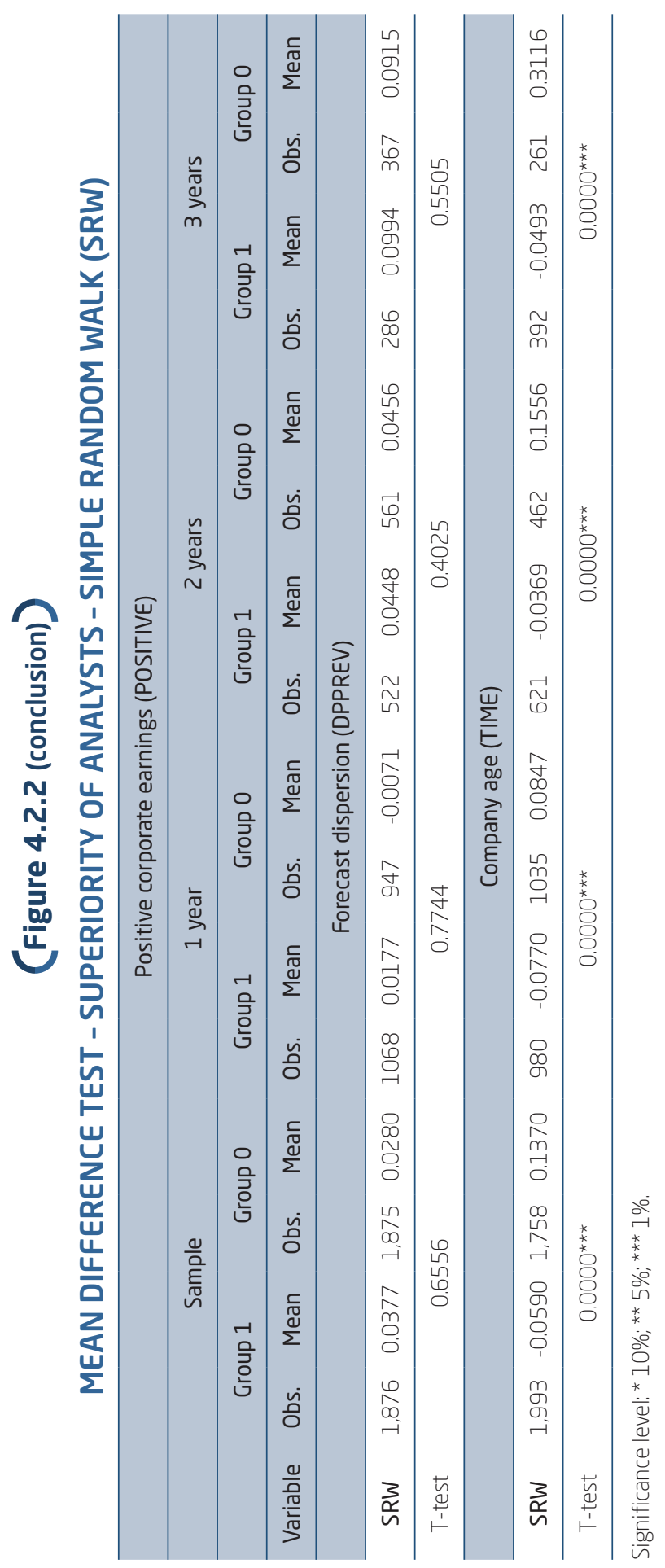

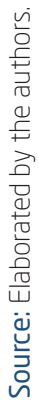




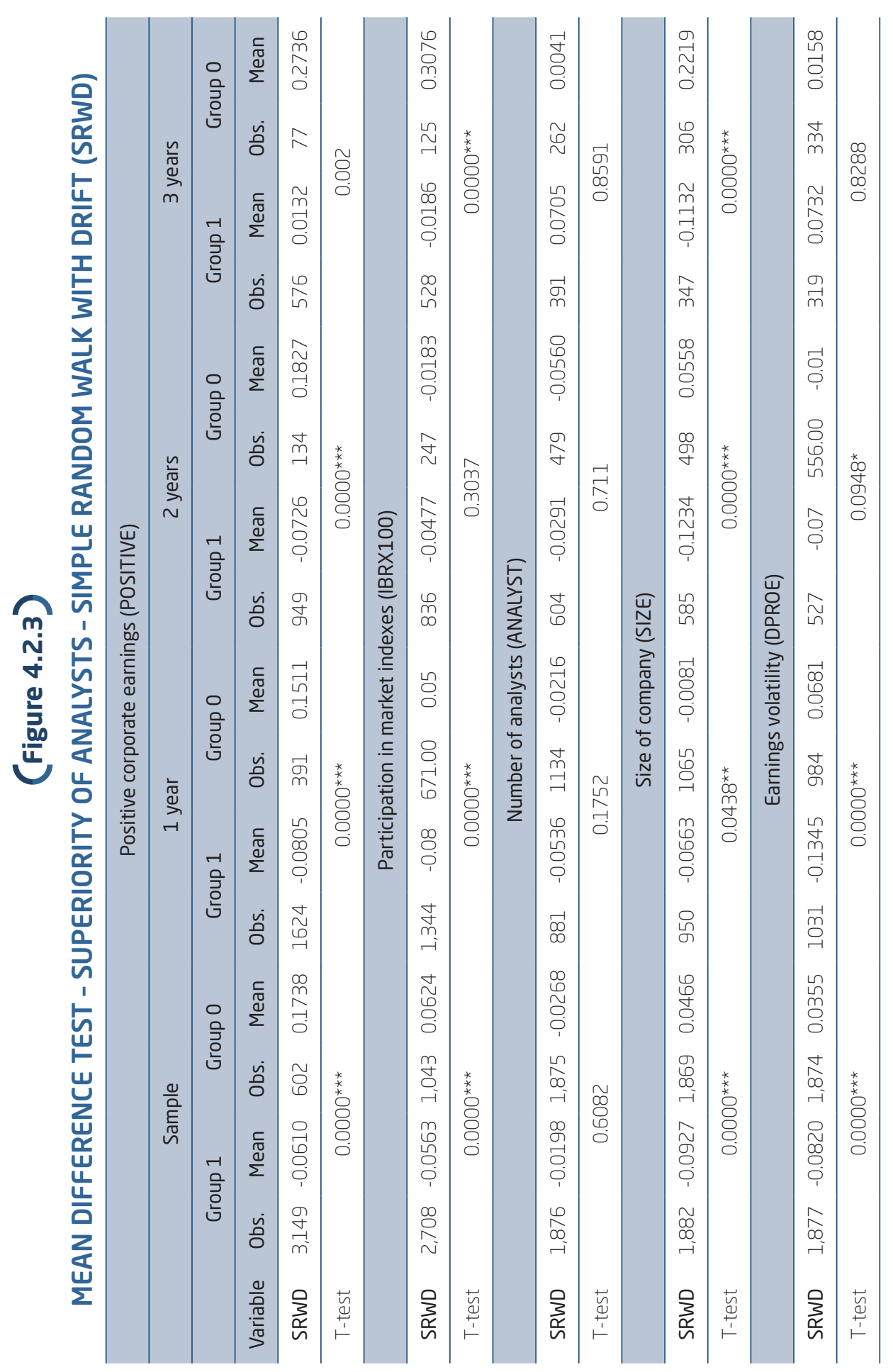




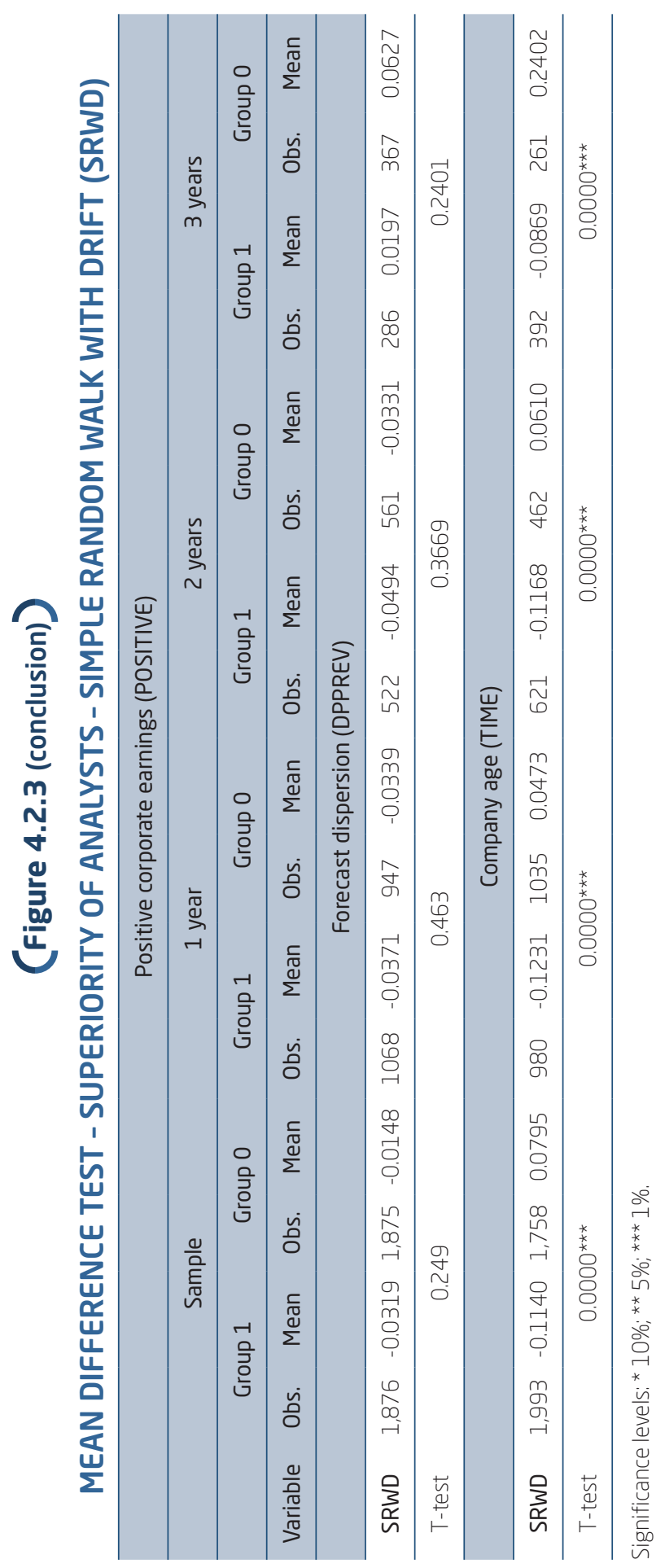

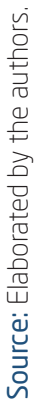


These results contradict the uncontested superiority of forecasts of company results by market analysts over time-series model estimates (Brown, Hagerman et al., 1987; Brown et al., 1987; Fried \& Givoly, 1982; Hopwood \& McKeown, 1982; O'Brien, 1988). This evidence is in line with findings from studies that re-evaluated the superiority of market analysts' long-term estimates (Bradshaw et al., 2012; Lacina et al., 2011).

However, the joint analysis of observations shows that market analyst forecasts are less accurate than random walk model estimates in the Brazilian case for both the short and long terms. This result is consistent with the study by Ball and Ghysels (2017), although they use a more complex timeseries methodology for the forecasts of future results of companies.

When compared to the results of the study by Silva (1998), these results support the importance of reassessing the superiority of analysts in Brazil, given that the previous study with a restricted sample indicated a greater accuracy of market analysts for the short and medium-term without evaluating the determinants of this superiority.

This result suggests the inefficiency of market analysts in transforming their temporal and informational advantages in the Brazilian capital market into a forecast accuracy greater than time-series models, except for brief periods (e. g., forecasts made in December and results revealed by March). Investors and researchers must use relatively more lagged predictions by market analysts with caution and must focus on using random walk forecasting - an inexpensive and straightforward method that provides more accurate results for Brazil.

As highlighted in the study, these results are based on the Brazilian capital market, which is different from the markets studied in international research (Bradshaw et al., 2012; Lacina et al., 2011). When compared to the sample used in these studies, Brazilian companies are smaller, analysts covering companies are fewer, the amount charged by analysts is restrictive for companies, and stock control is very concentrated. In Brazil, five main shareholders typically control more than $70 \%$ of the company's total traded shares (Pereira, Freitas, Vasconcelos, \& De Lucca, 2018). Moreover, Cotter et al. (2012) indicated that the adoption of the IFRS standard is associated with a higher quality of analysts' forecasts of future results of companies. The adoption of the IFRS standard is recent in Brazil, with mandatory adoption taking place in 2010 and studies presenting divergent results on the impact of the adoption on the quality of market analysts' forecasts (Gatsios \& Lima, 2014; Martinez \& Dumer, 2014). Finally, the low degree of institutional development found in international studies is highlighted (Djankov, McLiesh, \& Ramalho, 2006; La Porta, Lopez-de-Silanes, Shleifer, \& Vishny, 
1998; La Porta \& Shleifer, 2008) as an important factor to explain the low predictive power of analysts in Brazil.

\section{CONCLUSION}

This research examines the superiority of market analysts over random walk forecasting models in predicting future short and long-term results for publicly traded Brazilian companies.

The study marks a departure from the traditional literature, which argues that market analysts are superior in forecasting future company results and have informational and temporal advantages over time-series models (Brown, Hagerman et al., 1987, Brown et al., 1987; Fried \& Givoly, 1982; Hopwood \& McKeown, 1982; O’Brien, 1988).

However, the findings of new research call for a re-evaluation of the superiority of market analysts over time-series models. This study highlights that the superiority of analysts is not absolute, but depends on factors associated with forecast lag, number of analysts that cover the companies, dispersion of analyst estimates, variability of results, positive or negative results, company size, and time in the capital market (Ball \& Ghysels, 2017; Bradshaw et al., 2012; Lacina et al., 2011; Lorek \& Pagach, 2014).

Motivated by these recent studies and considering the absence of research in the context of Brazil, the current work evaluated the following research problem to examine the results of this line of research in a capital market still under development:

- Are the profit forecasts of market analysts superior to the forecasts provided by random walk models in the context of publicly traded Brazilian companies?

In this research, publicly-traded Brazilian companies were analyzed with data from 2010 to 2015. The research used information obtained from the Thomson Reuters ${ }^{\circledR}$ platform and the I/B/E/S ${ }^{\circledR}$ and Thomson Financial databases. The forecasts were observed with lags of one to three years. Forecasts with up to one year of lag were considered short-term estimates, and those with two or three years of lag were long-term. To complement the evaluation, these forecasts were observed in March, June, September, and December for each lag period.

The forecasts from analysts for the short term - one year of lag - were taken directly from the I/B/E/S® database. For long-term forecasts, the average rate of long-term growth was used. Time-series models were 
constructed using simple random walk forecast models and an adjusted random walk model with the real GDP growth of Brazil during this period.

The superiority of analysts was evaluated with the difference between the forecast errors of market analysts (SRW) and those of time-series models (SRWD) in each observation period. The determinants of analyst superiority were evaluated using company age, forecast horizon, earnings volatility, forecast dispersion, number of analysts, positive corporate earnings, size of the company, and participation in market indexes.

The results, supported by previous studies in the area (Lacina et al., 2011; Watts \& Leftwich, 1977), indicate greater forecasting accuracy for the simple random walk models compared to the growth random walk models for the general research sample. The combined analysis of publicly-traded Brazilian companies from 2010 to 2015 demonstrates no superiority for market analysts' forecasts of future results. The forecasting superiority of the analysts was confirmed only for a lag of three months. As discussed, these results contradict the uncontested superiority of market analysts' forecasts of company results over those of time-series models supported in the traditional literature (Brown, Hagerman et al., 1987; Fried \& Givoly, 1982; Hopwood \& McKeown, 1982; O’Brien, 1988).

Even so, the superiority of analysts was confirmed only for estimates divulged in December with a lag of three months, in the Brazilian case. These results approximate those of Ball and Ghysels (2017), who also indicate the superiority of time-series models over the short term. However, they are consistent with the findings of studies undertaken to re-evaluate the superiority of market analysts for long-term estimates (Bradshaw et al., 2012; Lacina et al., 2011).

These results suggest market analyst inefficiency in transforming temporal and informational advantages into greater forecasting accuracy, in comparison with time-series models, suggesting that investors and researchers should be cautious in using market analyst forecasts with a greater lag and pay greater attention to random walk forecasting - an inexpensive and straightforward method that provides more accurate results for Brazil. Finally, the results of this research are also relevant to the discussion on the cost and benefit of using market analyst estimates since the forecasting costs of analysts are greater than those of the simple forecasting models.

The results presented in this research are limited to the proposed method of evaluating the superiority of analysts. Future studies may consider using multivariate models to evaluate the factors that determine the superiority of market analysts and use more complex time series forecasting models for short- and long-term estimates in Brazil. 


\section{REEXAMINANDO A SUPERIORIDADE DOS ANALISTAS AO PREVEREM RESULTADOS DE EMPRESAS BRASILEIRAS DE CAPITAL ABERTO}

\section{RESUMO}

Objetivo: Esta pesquisa analisa a superioridade dos analistas com relação aos modelos random walk ao preverem os resultados de empresas brasileiras de capital aberto de curto e longo prazos.

Originalidade/valor: A literatura indica superioridade irrestrita dos analistas de mercado devido às suas vantagens de tempo e informação. Entretanto, recentes estudos da literatura internacional apontam para a necessidade de uma reavaliação dessa superioridade, indicando que, para determinadas características da empresa, e principalmente para estimativas de longo prazo, a superioridade dos analistas não é confirmada.

Design/metodologia/abordagem: Este trabalho avalia as previsões de lucro dos analistas e dos modelos random walk, simples e com crescimento, de curto e longo prazos, no período de 2010 a 2015 para as empresas brasileiras de capital aberto, utilizando dados com periodicidade anual.

Resultados: Os resultados indicam: 1. maior acurácia de previsão para os modelos random walk simples quando comparados com os modelos de random walk com crescimento; 2 . para a amostra total, nota-se maior acurácia da previsão dos modelos random walk, com superioridade dos analistas apenas para previsões com três meses de defasagem. A evidência sugere a superioridade de previsão dos modelos random walk quando comparados às previsões dos analistas de mercado. Os resultados sugerem baixa eficiência das previsões dos analistas de mercado para a previsão de resultado futuro das empresas brasileiras de capital aberto no período analisado.

\section{PALAVRAS-CHAVE}

Ganhos por ação. Superioridade dos analistas. Analistas de mercado. Modelos de séries temporais. Random walk. 


\section{REFERENCES}

Baghestani, H., \& Toledo, H. (2017). Do analysts' forecasts of term spread differential help predict directional chance in exchange rates? International Review of Economics \& Finance, 47(1), 62-69.

Ball, R., \& Ghysels, E. (2017). Automated earnings forecasts: Beat analysts or combine and conquer? Management Science, 64(10). doi:10.1287/mnsc. 2017.2864

Beiruth, A. X. (2012). Avaliação da utilização e precificação de modelos contábeis $e$ de analistas no mercado brasileiro (Dissertação de mestrado, Universidade de São Paulo, São Paulo, Brasil).

Boff, L. H., Procianoy, J. L., \& Hoppen, N. (2006). O uso de informações por analistas de investimento na avaliação de empresas: À procura de um padrão. Revista de Administração Contemporânea, 10, 169-192.

Bradshaw, M. T., Drake, M. S., Myers, J. N., \& Myers, L. A. (2012). A reexamination of analysts' superiority over time-series forecasts of annual earnings. Review of Accounting Studies, 17(1), 944-968.

Branson, B. C., Lorek, K. S., \& Pagach, D. P. (1995). Evidence on the superiority of analysts' quarterly earnings forecasts for small capitalization firms. Decision Sciences, 26(2), 243-263.

Brown, L. D. (1993). Earnings forecasting research: Its implications for capital markets research. International Journal of Forecasting, 9, 295-320.

Brown, L. D., Hagerman, R. L., Griffin, P. A., \& Zmijewski, M. E. (1987). An evaluation of alternative proxies for the market's assessment of unexpected earnings. Journal of Accounting and Economics, 9(2), 159-193.

Brown, L. D., Richardson, G. D., \& Schwager, S. J. (1987). An information interpretation of financial analyst superiority in forecasting earnings. Journal of Accounting Research, 25(1), 49-67.

Brown, L. D., \& Rozeff, M. S. (1978). The superiority of analyst forecasts as measures of earnings expectations: Evidence from earnings. The Journal of Finance, 33(1), 1-16.

Cheng, J., Fan, D., \& So, R. (2003). On the performance of naive, analyst and composite earnings forecasts: Evidence from Hong Kong. Journal of International Financial Management \& Accounting, 14, 146-165.

Chiang, H. T., \& Chia, F. (2005). Analyst's financial forecast accuracy and corporate transparency. Proceedings of the Academy of Accounting and Financial Studies, 10(1), 9-14. 
Cotter, J., Tarca, A., \& Wee, M. (2012). IFRS adoption and analysts' earnings forecasts: Australian evidence. Accounting and Finance, 52 (2), 395-419.

Dalmácio, F. Z., Lopes, A. B., \& Sarlo, A. A., Neto (2013). Uma análise da relação entre governança corporativa e acurácia das previsões dos analistas do mercado brasileiro. Revista de Administração Mackenzie, 14(5), 104-139.

Dechow, P. M., Hutton, A. P., \& Sloan, R. G. (2000). The relation between analysts' forecasts of long-term earnings growth and stock price performance following equity offerings. Contemporary Accounting Research, 17, 1-32.

Dechow, P. M., \& Schrand, C. M. (2004). Earnings quality. Virginia: CFA Institute.

Djankov, S., McLiesh, C., \& Ramalho, R. M. (2006). Regulation and growth. Economic Letters, 92, 395-40.

Dugar, A., \& Nathan, S. (1995). The effect of investment banking relationships on financial analysts' earnings forecasts and investments recommendations. Contemporary Accounting Research, 12(1), 131-160.

Eid, W., Jr., \& Rochman, R. R. (2006). Analysts' recommendations in Brazil: Do they add value? Balas: Peru.

Esteter, B., Pedreira, B. E., \& Barros, L. A. B. C. (2011). Análise dos erros de previsão em empresas de capital aberto para os mercados de Argentina, Brasil, Chile e México entre os anos de 2003 a 2009. II Congresso Nacional de Administraçãa e Ciências Contábeis, Rio de Janeiro, RJ, Brasil.

Francis, J., \& Philbrick, D. (1993). Analysts decisions as products of a multitask environment. Journal of Accounting Research, 31 (2), 216-230.

Fried, D., \& Givoly, D. (1982). Financial analysts' forecasts of earnings: A better surrogate for market expectations. Journal of Accounting and Economics, 4, 85-107.

Gatsios, R. C., \& Lima, F. G. (2014). Acurácia dos analistas: Impacto da adoção do padrão IFRS sobre a qualidade preditiva da informação contábil no Brasil. Encontro Brasileiro de Finanças, Recife, PE, Brasil, 14.

Gatsios, R. C., Lima, F. G., \& Assaf, A., Neto (2016). Viés de previsão das estimativas dos analistas de mercado em um país emergente: Impacto da adoção do padrão IFRS no Brasil. Encontro Brasileiro de Finanças, Recife, PE, Brasil, 16.

Goojier, J. G., \& Hyndman, R. J. (2006). 25 years of time series forecasting. International Journal of Forecasting, 22, 443-473.

Grigaliuniene, Z. (2013). Time-series models forecasting performance in the Baltic stock market. Organizations and Markets in Emerging Economies, 4, 104-120. 
Gu, Z., \& Wu, J. (2003). Earnings skewness and analyst forecast bias. Journal of Accounting and Economics, 35, 5-29.

Hope, O. K. (2003). Disclosure practices, enforcement of accounting standards, and analysts forecast accuracy: An international study. Journal of Accounting Research, 2, 235-272.

Hopwood, W. S., \& McKeown, J. C. (1982). Evidence on surrogates for earnings expectations within a capital market context. Journal on Accounting, Auditing and Finance, 5, 339-368.

Kothari, S. P. (2001). Capital market research in accounting. Journal of Accounting and Economics, 31, 105-231.

Kross, W., Ro, B., \& Schroeder, D. (1990). The analysts' information advantage. The Accounting Review, 65(2), 461-476.

Lacina, M., Lee, B. B., \& Xu, R. Z. (2011). An evaluation of financial analysts and naïve methods in forecasting long-term earnings. In K. D Lawrence \& R. K. Klimberg (Eds.), Advances in business and management forecasting (pp. 77-101). Bingley, UK: Emerald.

Lang, M., \& Lundholm, R. (1996). Corporate disclosure policy and analyst behavior. The Accounting Review, 71 (4), 467-492.

La Porta, R., Lopez-de-Silanes, F., Shleifer, A., \& Vishny, R. (1998). Law and finance. Journal of Political Economy, 106(6), 1113-1155.

La Porta, R., \& Shleifer, A. (2008). The unofficial economy and economic development. Brookings Papers on Economic Activity, 39 (2), 275-363.

Lim, T. (2002). Rationality and analysts' forecast bias. Journal of Finance, 56(1), 369-385.

Lima, M. P., \& Almeida, V. S. (2015). Os analistas sell-side fazem boas previsões de preços-alvo no Brasil? Revista Brasileira de Finanças, 13 (3), 365-393.

Lorek, S. K., \& Pagach, D. P. (2014). Analysts versus time-series forecasts of quarterly earnings: A maintained hypothesis revisited. Recuperado de https://ssrn. com/abstract $=2406013$

Lorek, S. K., \& Willinger, L. G. (2002) An analysis of the accuracy of longterm earnings predictions. Advances in Accounting, 19, 161-175.

Martinez, A. L. (2004). Analisando os analistas: Estudo empírico das projeções de lucros e das recomendações dos analistas de mercado de capitais para as empresas brasileiras de capital aberto (Tese de doutorado, Fundação Getúlio Vargas, São Paulo, Brasil).

Martinez, A. L. (2007). Otimismo e viés de seleção dos analistas. Brazilian Business Review, 4(2), 104-118. 
Martinez, A. L., \& Dumer, M. (2014). Adoption of IFRS and the properties of analysts' forecasts: The Brazilian case. Revista de Contabilidade e Organizações, 8(20), 3-16.

McNichols, M. F., \& O’Brien, P. C. (1997). Self-selection and analyst coverage. Journal of Accounting Research, 35, 167-199.

Mikhail, M., Walthier, B., \& Willis, R. (1997). Do security analysts improve their performance with experience? Journal of Accounting Research, 35, 131-157.

O’Brien, P. C. (1988). Analysts' forecasts as earnings expectations. Journal of Accounting and Economics, 10(1), 53-83.

Paulo, E., Lima, G. A. S. F., \& Lima, I. S. (2006). A influência da cobertura dos analistas financeiros sobre o gerenciamento de resultados das companhias abertas brasileiras. Congresso USP de Controladoria e Contabilidade, São Paulo, SP, Brasil, 16.

Pereira, G. M. L., Freitas, M. R. O., Vasconcelos, A. C., \& De Lucca, M. M. M. (2018). Reflexos da concentração acionária e da estrutura do conselho de administração na remuneração de altos executivos em empresas brasileiras. Congresso USP de Controladoria e Contabilidade, São Paulo, SP, Brasil, 18.

Ramnath, S., Rock, S., \& Shane, P. (2008). The financial analyst forecasting literature: A taxonomy with suggestions for further research. International Journal of Forecasting, 24(1), 34-75.

Schipper, K. (1991). Analysts' forecasts. Accounting Horizons, 5, 105-131.

Silva, H. R. L. F. (1998). A capacidade previsionária no mercado acionário brasileiro: Um estudo focado nas previsões dos analistas de investimentos. Encontro da Associação Nacional de Pós-Graduação e Pesquisa em Administração, Foz do Iguaçu, RS, 32.

Watts, R. L., \& Leftwich, R. W. (1997). The time series of annual accounting earnings. Journal of Accounting Research, 15(2), 253-271.

\section{AUTHOR NOTES}

Rafael C. Gatsios, PhD from the Faculty of Economics, Administration and Accounting of Ribeirão Preto (FEA-RP), University of São Paulo (USP); Fabiano G. Lima, PhD from FEA-RP, USP; Luiz E. Gaio, PhD from FEA-RP, USP; Tabajara Pimenta Junior, PhD from FEA-RP, USP. 
Rafael C. Gatsios is now professor at FEA-RP of USP; Fabiano G. Lima is now professor at FEARP of USP; Luiz E. Gaio is now professor at the Faculty of Applied Sciences (FCA) of Campinas State University (Unicamp); Tabajara Pimenta Junior is now professor at FEA-RP of USP.

Correspondence concerning this article should be addressed to Rafael C. Gatsios, Avenida dos Bandeirantes, 3900, Campos Elísios, Ribeirão Preto, São Paulo, Brazil, CEP 14040-905.

E-mail: rafaelgatsios@fearp.usp.br

\section{EDITORIAL BOARD}

\section{Editor-in-chief}

Gilberto Perez

\section{Associated editor}

Flávio Luiz de Moraes Barboza

Technical support

Vitória Batista Santos Silva

\section{EDITORIAL PRODUCTION}

Publishing coordination

Jéssica Dametta

Layout designer

Emap

Editorial intern

Paula Di Sessa Vavlis

Graphic designer

Libro
Language editor

Daniel de Almeida Leão 